\title{
Measuring socio-economic inequality: From dwellers' perspective within Bangalore urban agglomeration
}

\author{
Keya Chakraborty \\ Centre for Infrastructure, Sustainable Transportation, and Urban Planning, Indian Institute of Science, \\ Bangalore, India \\ keyas80@gmail.com
}

\begin{abstract}
Planners and researchers have realized that larger regional framework of urban areas are significant in assessing various inequality aspects in a developing country like India. The framework consists of heterogeneity in spatial and demographic aspects and in quality of socio-economic development levels as well. Against this background, the present paper has proposed a methodological framework to assess socio-economic inequality within Bangalore Urban Agglomeration (BUA) as governed by the composite set of Human Development Index (HDI) based indicators. Assessments are based on local data of dwellers' preferences on the indicators. On the whole, this paper has tried to establish the significance of application of HDI based indicators in an assessment of socio-economic inequality within BUA. Consequently, the paper has arrived at the need for improvement of comprehensive HDI governed basic public services, amenities, and advanced facilities, across all trans-urban-area levels to ensure a holistic development within BUA.
\end{abstract}

Keywords: agglomeration, inequality, HDI indicators, urban governance

\section{INTRODUCTION}

The recent urban development has explored substantial changes in the framework of urban agglomeration and this framework cannot be explained by the existing empirical model (Cladera et al., 2009). Urban planners and policy makers have realized that a more appropriate scale for assessing socio-economic inequality within an urban agglomeration in a developing country is its larger regional framework (Burges \& Jenks, 2000; Wall Street Journal Report, 2005). The framework exhibits two aspects viz. first heterogeneity in spatial and demographic characteristics and secondly consequential inequality in quality of socio-economic development levels. United Nations Development Program (UNDP) has emphasized a need to assess socio-economic inequality considering the aforesaid two aspects. Across the world each region has a specific environment and cultural heritage based on which wide range of indicators has been developed that employ differing methodologies to measure human development (Gallardo, 2009). Till date the selection of indicators for assessing spatial inequality of a large area is based on mathematical and statistical derivations, avoiding normative aspects of human life. Based on this need the first objective of the present paper is to develop a set of parameters based on Human Development Index (HDI) which are embraced by the dwellers of Bangalore Urban Agglomeration (BUA) and reflects their aspirations towards an enriched life.
The second objective is to propose a methodological framework to assess socioeconomic inequality within BUA. The assessment is governed by HDI based indicators viz., education, economy, and health. Finally, based on the assessment this paper tries to establish an improved governance of basic services and amenities, suggested by dwellers within BUA.

\section{LITERATURE}

Research in urban agglomerations established a long analytical tradition in socio-economic studies (Phelps, 2004). The two aspects (quantitative and qualitative) of socio-economic inequality within urban agglomeration differ from standpoint of a developed and a developing economy (Birdsall et al., 2011; Kundu, 1992; Sivaramakrishnan et al, 2005). In case of a developing country urban geographers, physical planners and social policy makers are more interested to focus on distribution of settlements and extended metropolitan forms of East Asia, instead of a single and compact urban form (Burges \& Jenks, 2000; Dick \& Rimmer, 1998; Wall Street Journal Report, 2005). The larger regional framework of an urban agglomeration exhibits a significant extent of heterogeneity and consequential socio-economic inequality across the agglomeration having varying development levels within it (Atkinson, 1992; Shukla \& Bauer, 2009). These levels are indicated by a variety of factors ranging from general income based socioeconomic parameters to multi-dimensional 
parameters representing other normative frontiers of development (Bartsch, 2011; Bhaumik \& Chakraborty, 2006; Panda \& Agarwal, 2005). It is evident from recent researches that the objective of India's national development should not be just to abolish income based inequalities in development but minimize inequalities in its multiple aspects (Aluwahlia, 2010). In this respect, recent research has emphasized three principal indicators of development a) economic development based on growth and employment, b) social development based on education to endow people with human capital, and c) health facilities based on availability of basic medical services. Incidentally, the three aforesaid principal indicators, i.e., economic development, level of education, and availability of health facilities, all collectively constituting socioeconomic development, are synonymous with three principle indicators of HDI (Human Development Reports, 1990). As India is a widely diverse country, socio-economic inequality levels in India vary within states or regions and between rural and urban areas within a state (Desai et al., 2010; Vanneman \& Dubey, 2010). According to the Human Development Report (Human Development Reports, 2013) of the United Nations Development Program (UNDP), India ranks 136, which implies medium human development with HDI value of 0.554. Planning Commission Government of India (2002) has felt the need of the balanced development policies in minimizing the multiple aspects of inequality in different levels of spatial as well as socio-economic sectors within India (Aluwahlia, 2010).

Researchers have also pointed out the importance of a relationship between the levels of indicator of HDI and the role of different forms of local governance within an urban agglomeration (Charlesworth \& Cochrane, 1994; Kanbur et al., 2006; Ke \& He 2009; Kim, 2008). According to empirical assumption the urban societal preference significantly effects on the spatial arrangement of urban agglomeration, which can be defined as a spatial correlation of human activities (Anderson et al., 1996; Schretzenmayr et al., 2009). Based on the same, an assessment of dwellers' perception and their preferences on future governance establishes the bases of the research of this paper. Existing studies have shown that need of assessing socioeconomic inequality based on a) the present and future levels of indicators of HDI and b) its impact on metropolitan governance as perceived by the dwellers is significant (Feenstra \& Hanson, 1996; Pinelopi \& Pavcnik, 2007). Till date, minimizing socio-economic inequality within an urban agglomeration in light of dwellers' preference remains as unexplored area of assessment. As societies are dynamic with time, selection of indicators based on dwellers' preferences is a challenging work (Tai-Kei \& Coates, 2002; Gallardo, 2009). This paper selects a range of parameters under each of three HDI based indicators that reflect the best possible options of dwellers within BUA. Also the paper put an effort to establish a methodological framework to assess the extent of socio-economic inequality within BUA based on dwellers' perspective.

\section{METHODOLOGY}

The study entirely based on primary data collected from household survey within BUA in the year 2013. According to Bruhat Bangalore Mahanagara Palike (BBMP), BUA is divided into eight zones (refer Fig. 1, Directorate of Census Operations of Karnataka, 2013). Primary data is collected from east zone of BBMP, to represent BUA. Based on the population density the entire zone is subdivided into five sub-zones. These are Sub zone North $(\mathrm{SzN})$, Sub zone East (SzE), Sub zone Central (SzC), Sub zone South (SzS), Sub zone West $(\mathrm{SzW})$. In the present research total numbers of household surveys have been divided within east zone. Based on ward population density contribution of each of the sub-zone to total (refer Table 1) sample size is calculated. Ascending weightings are given as:

$\mu=0.359 \times 5+0.298 \times 4+0.174 \times 3+0.096 \times 2+0.073 \times 1=3.8$.

So, $\mathrm{O} 2=0.359(5-3.8) 2+0.298(4-3.8) 2+0.174(3-3.8) 2+0.096(2-3.8) 2+0.073(1-3.8) 2=1.8$

For $95 \%$ confidence and density tolerance limit as $1(\mathrm{e}) ; \mathrm{n}=3.84 \mathrm{O} 2 / \mathrm{e} 2=6.912$

For $95 \%$ confidence and density tolerance 0.75

$\mathrm{n}=12.28$ which is $<13$ or the targeted sampling size per ward. 
Table 1: Logic of sample size and number of collected sample

\begin{tabular}{|l|c|c|c|c|c|}
\hline \multicolumn{1}{|c|}{ All sub-zones } & SZ-North & SZ-Central & SZ-West & SZ-East & SZ-South \\
\hline $\begin{array}{l}\text { Ward based contribution by population } \\
\text { density (\%) }\end{array}$ & 35.9 & 29.8 & 17.4 & 9.6 & 7.3 \\
\hline Total no. of wards in each sub-zones & 10 & 8 & 7 & 6 & 5 \\
\hline $\begin{array}{l}\text { Sample size according to density (as min. } \\
\text { =13) }\end{array}$ & 130 & 104 & 91 & 78 & 65 \\
\hline
\end{tabular}

Table 2: Deduction of parameters from indicators

\begin{tabular}{|l|l|}
\hline \multicolumn{1}{|c|}{ Indicators } & \multicolumn{1}{c|}{ Parameters } \\
\hline \multirow{5}{*}{ Education } & $\begin{array}{l}\text { 1. Total no. of family members attending/attended education } \\
\text { 2. Nature of attending educational institute } \\
\text { 3. Expenditure on education for last year (/month in Rs } \\
\text { 4. Loan for education } \\
\text { 5. Perception of current state of education services }\end{array}$ \\
\hline Economy & $\begin{array}{l}\text { 1. Total number of earning members in the family } \\
\text { 2. Nature of employment } \\
\text { 4. Family expenditure } \\
\text { 5. Family income savings/investments } \\
\text { 6. Perception of current state of employment opportunities }\end{array}$ \\
\hline \multirow{5}{*}{ Health } & $\begin{array}{l}\text { 1. Total number of family members availing medical services } \\
\text { 2. Nature of medical institutions being attended } \\
\text { 3. Aggregate expenditure on health for last year (/month in Rs) } \\
\text { 4. Health insurance } \\
\text { 5. Perception of current state }\end{array}$ \\
\hline
\end{tabular}

Sampling size shows that 13 household surveys under each of the ward from five sub-zones are the minimum requirement. This led to a total of 468 surveys which matches to the aggregate minimum. The households are selected randomly from ward level of each of the sub-zones. The list of the wards is gathered from Bangalore Urban District at a Glance: 2009 - 2010. Personal interview method is the only way of collecting primary data from the respondents. At the door of each house a coin is tossed to decide whether interview will be taken of that household or not. In each selected household, only present adult who is willing to participate in the survey, is recruited. The sample accounts for about $25 \%$ of all the households in visited wards.

Based on human development indicators, all three indicators are divided into several parameters. These are presented in Table 2.
Dwellers' perception on present situation of HDI based indicators is calculated based on nine point scale for each parameter say, amount of educational loan. Additionally, for calculating their future preferences they have been asked to rank the parameters in terms of their importance as 'least important', 'less important', and 'equally important', 'more important', and 'most important'. The ranks are converted to weightings based on five point scale viz. $0.20,0.33,1.0,3.0$, and 5.0 respectively. Choice of this relative weight is typically based on trial and error method that suits the research objective most. In the present paper dwellers' weighted preferences for present situation are termed as 'scaled value'. To get an illustrated view of dwellers' present situation and preferences, detailed analyses have been done based on scaled values of parameters under each of the indicator. 


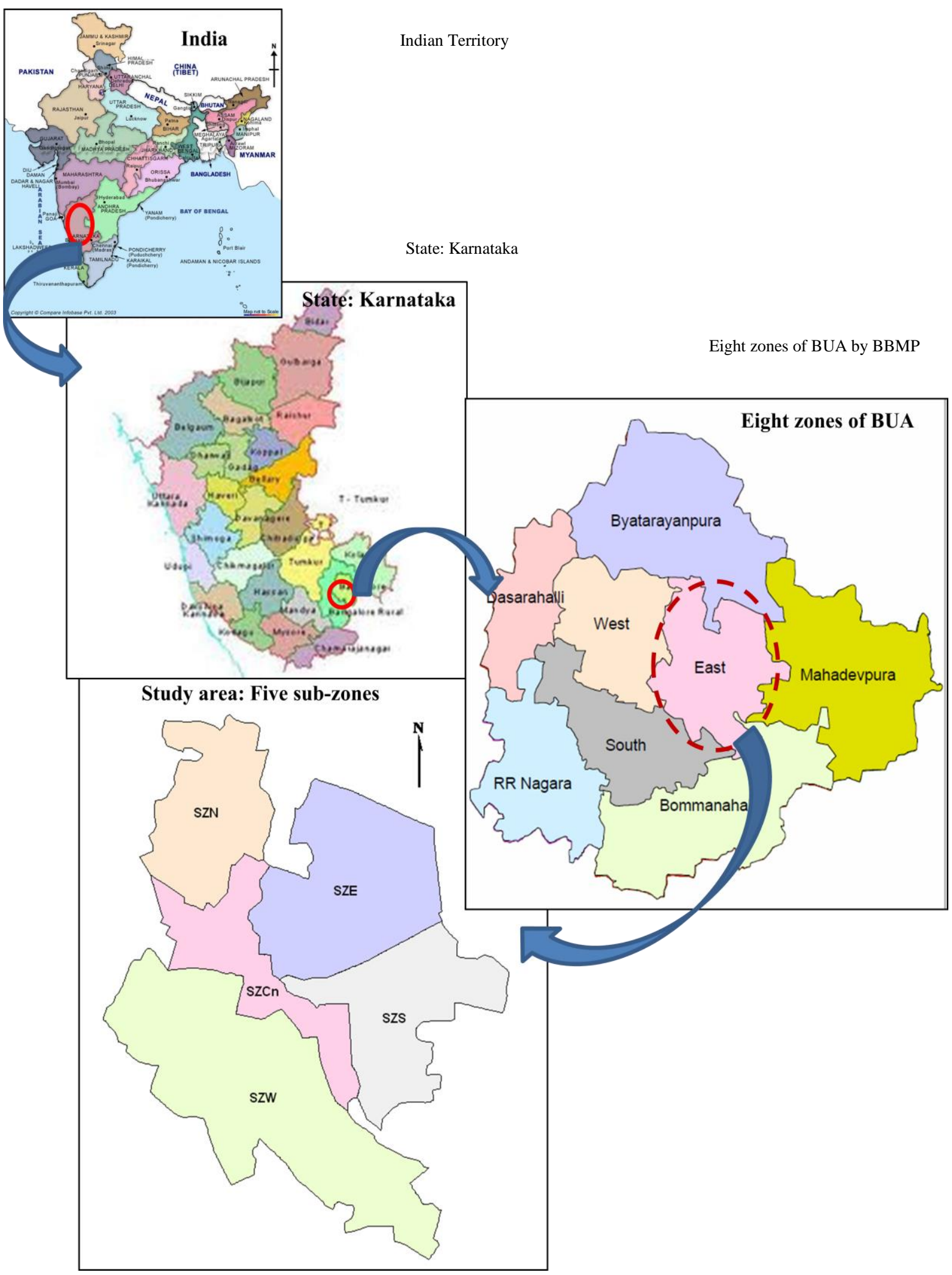

Figure 1: Study area 


\subsection{ASSESSMENT OF DWELLERS' PRESENT SITUATION: CHARACTERISTIC VECTOR $(R I J)$}

The mean of scaled values on dwellers' present situation are termed as characteristic vectors, i.e., $R_{i j} . R_{i j}$ is calculated based on dwellers' present priorities on indicators of HDI, viz, education, health, and economy. Table 3 presents the calculation of characteristic vector for an indicator.

\subsection{ASSESSMENT OF DWELLERS' PREFERENCE: PRIORITY VECTORS (WIJ)}

The mean of scaled values of dwellers' preferences on parameters of HDI indicators are computed as priority vector, i.e., $W_{i j}$. Mean value of each parameter for the entire eight sub-regions has been calculated based on Analytic Hierarchy Process (AHP) to get metropolitan average. It is a systematic procedure for representing the basic elements of variables under analysis in their pairwise comparison, i.e., in a matrix, in the hierarchy (Saaty \& Kearns, 1985). AHP plays a significant role in decision making from a wide variety of options (Sun et al., 2009). The process, instead of finding out of the correct one, helps to find out the best option, which suits dwellers' preferences or aspiration levels. In the present research AHP has formed a framework for dwellers' preferences and quantified parameters to meet dwellers' aspirations. Table 4 presents the calculation of priority vector for an indicator.

Table 3: Computation of characteristic vectors $\left(R_{i j}\right)$ for an indicator

\begin{tabular}{|l|c|c|c|c|c|c|}
\hline Five sub-zones & $\begin{array}{c}\text { Parameter } \\
(j=1)\end{array}$ & $\begin{array}{c}\text { Parameter } \\
(j=2)\end{array}$ & Parameter $(j=3)$ &.. & $(j=\mathrm{n})$ & Total of each sub-region \\
\hline SzN-sz $(i=1)$ & $a_{11}$ & $a_{12}$ & $a_{13}$ &.. & $a_{1 n}$ & $\sum_{j=1}^{n} a_{1 j}$ \\
\hline SzE-sz $(i=2)$ & $a_{21}$ & $a_{22}$ & $a_{23}$ &.. & $a_{2 n}$ & $\sum_{j=1}^{n} a_{2 j}$ \\
\hline.. &.. &.. &.. & $a_{i j}$ &.. &.. \\
\hline SzW-sz $(i=m)$ & $a_{m 1}$ & $a_{m 2}$ & $a_{m 3}$ &.. & $a_{m n}$ & $\sum_{j=1}^{n} a_{m j}$ \\
\hline
\end{tabular}

Table 4: Computation of priority vectors $\left(\mathrm{W}_{\mathrm{ij}}\right)$ for an indicator

\begin{tabular}{|l|c|c|c|c|c|c|}
\hline \multicolumn{1}{|c|}{ Five sub-zones } & $\begin{array}{c}\text { Parameter } \\
(j=1)\end{array}$ & $\begin{array}{c}\text { Parameter } \\
(j=2)\end{array}$ & $\begin{array}{c}\text { Parameter } \\
(j=3)\end{array}$ &.. & $(j=\mathrm{n})$ & $\begin{array}{c}\text { Total of each } \\
\text { sub-region }\end{array}$ \\
\hline SzN-sz $(i=1)$ & $b_{11}$ & $b_{12}$ & $b_{13}$ &.. & $b_{1 n}$ & $\sum_{j=1}^{n} b_{1 j}$ \\
\hline SzE-sz $(i=2)$ & $b_{21}$ & $b_{22}$ & $b_{23}$ &.. & $b_{2 n}$ & $\sum_{j=1}^{n} b_{2 j}$ \\
\hline.. &.. &.. &.. & $b_{i j}$ &.. &.. \\
\hline SzW-sz $(i=m)$ & $b_{m 1}$ & $b_{m 2}$ & $b_{m 3}$ &.. & $b_{m n}$ & $\sum_{j=1}^{n} b_{m j}$ \\
\hline
\end{tabular}




\subsection{ASSESSMENT PRIORITIZED \\ OF DWELLERS PREFERENCE: COMPOUNDED WEIGHTING VECTORS $($ CIJ $)$}

From the mean value of priority vectors $\left(W_{i j}\right)$ and the characteristic vectors $\left(R_{i j}\right)$ the compounded weighting vector $\left(\mathrm{C}_{i j}\right)$ has been calculated. $\mathrm{C}_{i j}$ represents aggregate current situation of the eight sub-regions for three indicators of HDI. Considering Table 3 and Table 4 say, for example taking education related parameters, $\mathrm{C}_{i j}$ of education for a particular $j^{\text {th }}$ sub-zone, say $\mathrm{SzN}-\mathrm{sz}$ is:

$\mathrm{C}_{i j}=\mathrm{W}_{i j} * \mathrm{R}_{i j}$ where, $\mathrm{W}_{i j} * \mathrm{R}_{i j}=a_{11} * b_{11}+a_{12} * b_{12}+\ldots a_{n m} * b_{n m}$ for $j^{\text {th }}$ sub-region, here $\mathrm{SzN}-\mathrm{sz}$.

Similarly, $\mathrm{C}_{i j}$ of other sub-regions has been calculated based on the same formula for education as well as other parameters of all HDI based indicators (refer Table 5). Based on total compounded weighting vectors $\left(C_{i j}\right)$, mean of BUA has been calculated. Inequality of a particular indicator across five sub-zones is calculated based on minimum and maximum of $C_{i j}$. Following the similar steps of calculation, inequality for each of the indicator has been calculated (refer Table 6). The concept of maxima-minima against urban agglomeration mean and the consequent understanding of inequality are presented in Figure 2.

Table 5: Computation of compounded weighting vector $\left(C_{i j}\right)$ for a sub-region

\begin{tabular}{|c|c|c|c|c|c|c|}
\hline $\begin{array}{c}\text { Five } \\
\text { sub- } \\
\text { zones }\end{array}$ & $\begin{array}{l}\text { Parameter } \\
\quad(j=1)\end{array}$ & $\begin{array}{l}\text { Parameter } \\
\quad(j=2)\end{array}$ & $\begin{array}{l}\text { Parameter } \\
\quad(j=3)\end{array}$ & .. & $\begin{array}{l}\text { Parameter } \\
(j=\mathrm{n})\end{array}$ & $\begin{array}{l}\text { Total of } \\
\text { each sub- } \\
\text { region (A) }\end{array}$ \\
\hline $\begin{array}{l}\text { SzN-sz } \\
(i=1)\end{array}$ & $c_{11}=\left(a_{11} * b_{11}\right)$ & $c_{12}=\left(a_{12} * b_{12}\right)$ & $c_{13}=\left(a_{13} * b_{13}\right)$ & .. & $c_{\ln }$ & $\sum_{j=1} c_{1 j}$ \\
\hline $\begin{array}{l}\text { SzE-sz } \\
(i=2)\end{array}$ & $c_{21}=\left(a_{21} * b_{21}\right)$ & $c_{22}=\left(a_{22} * b_{22}\right)$ & $c_{23}=\left(a_{23} * b_{23}\right)$ & .. & $c_{2 n}$ & $\sum_{j=1}^{n} c_{2 j}$ \\
\hline.. & .. & .. & .. & $c_{i j}$ & .. & .. \\
\hline $\begin{array}{l}\text { SzW-sz } \\
(i=m)\end{array}$ & $c_{m l}=\left(a_{m l} * b_{m l}\right)$ & $c_{m 2}=\left(a_{m 2} * b_{m 2}\right)$ & $\begin{array}{c}c_{m 3}=\left(a_{m 3} *\right. \\
\left.b_{m 3}\right)\end{array}$ & .. & $c_{m n}$ & $\sum_{j=1}^{n} c_{m j}$ \\
\hline Total & $\sum_{i=1}^{m} c_{i 1}$ & $\sum_{i=1}^{m} c_{i 2}$ & $\sum_{i=1}^{m} c_{i 3}$ & .. & $\sum_{i=1}^{m} c_{i n}$ & $\sum \mathrm{A}$ \\
\hline
\end{tabular}

Table 6: Calculation for inequality for a particular indicator over sub-zones

\begin{tabular}{|c|c|c|}
\hline BUA mean & Inequality & Inequality $\left( \pm I_{l}\right)+\left( \pm I_{2}\right) * 100$ \\
\hline \multirow{2}{*}{$\mu=\sum \boldsymbol{A} \div \boldsymbol{n}$} & $I_{l}=$ Maximum $\mathrm{C}_{i j}-\mu$ & \multirow{2}{*}{ Inequality of an indicator } \\
\cline { 2 - 2 } & $I_{2}=$ Minimum $\mathrm{C}_{i j}-\mu$ & \\
\hline
\end{tabular}

Note: $n=$ Number of sub-zones
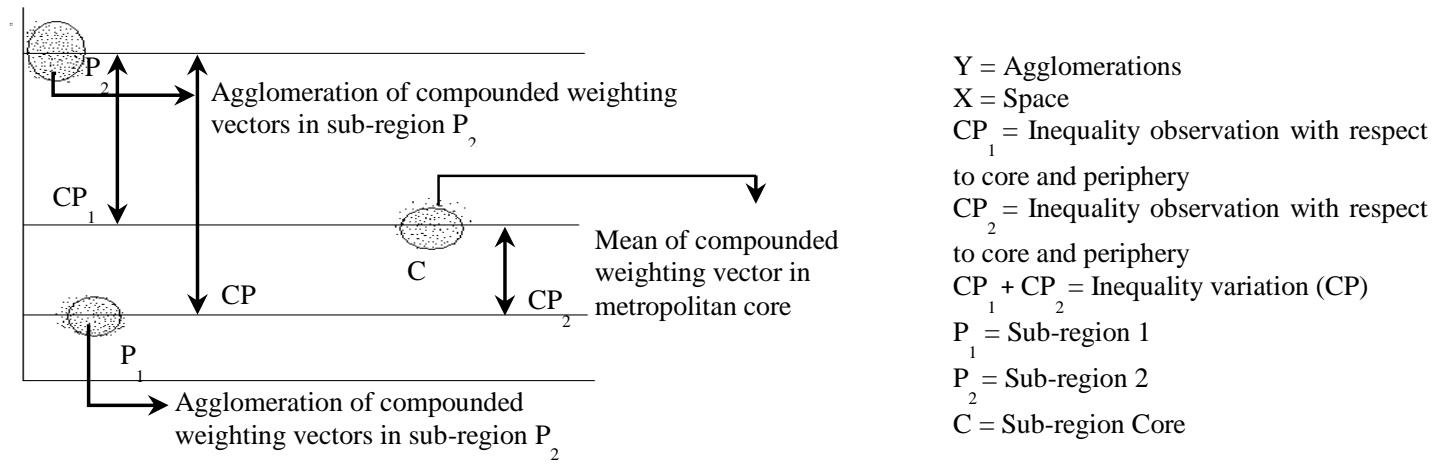

Figure 2: Conceptual diagram for understanding extent of inequality based on maxima and minima values against a main city value 


\subsection{AGGREGATE HDI: WEIGHTING VECTORS $(C)$}

COMPOSITE

Based on $C_{i j}$, composite weighting vectors for each indicator of each sub-region has been calculated. Levels of inequality of each indicator within subregions have also been calculated (refer Table 7). Aggregate HDI has been calculated for entire five sub-zones, which represents BUA as a whole. Finally, following the similar aforesaid minimamaxima concept of inequality, it has been calculated for BUA (refer Table 8).

\subsection{ASSESSMENT OF DWELLERS' PREFERENCE ON FUTURE METROPOLITAN GOVERNANCE}

Assessment of inequality in dwellers' preference for nature of future governance is used to augment efficiency of the socio-economic infrastructural systems and consequent minimization of inequality within BUA. The preferences of governance patterns are a) absolute public ownership or b) absolute private ownership or c) hybrid publicprivate-partnership (ppp) (Table 9).

Dwellers' have been asked to rank their preferences regarding future governance based on HDI indicators of education, economy, and health. The ranks are converted into weightings, e.g., 0.2, $0.4,1.0,2.5$, and 5.0 for the five options of extremely poor, poor, moderate, high, extremely high. AHP based on a C-program computer code has been similarly applied to analyze the data to obtain the priority vectors for the three different governance options. Table 9 furnishes the preferences of governance pattern with respect to an indicator of HDI. Similar calculation has been used to obtain preferences on governance for all the indicators of HDI.

Table 7: Computation of composite weighting vector $(C)$ for BUA

\begin{tabular}{|l|c|c|c|c|}
\hline \multicolumn{1}{|c|}{$\begin{array}{c}\text { Five sub- } \\
\text { zones }\end{array}$} & $\begin{array}{c}\text { Education (values of } \\
\left.C_{i j}\right) a_{i}\end{array}$ & $\begin{array}{c}\text { Economy } \\
\left.\text { (values of } C_{i j}\right) b_{i}\end{array}$ & $\begin{array}{c}\text { Health } \\
\left.\text { (values of } C_{i j}\right) c_{i}\end{array}$ & $\begin{array}{c}\text { Total of each sub-region } \\
(C)\end{array}$ \\
\hline SzN-sz $(i=1)$ & $a_{1}$ & $b_{1}$ & $c_{1}$ & $\sum a_{1}+b_{1}+c_{1}$ \\
\hline SzE-sz $(i=2)$ & $a_{2}$ & $b_{2}$ & $c_{2}$ & $\sum a_{2}+b_{2}+c_{2}$ \\
\hline.. &.. &.. & $c_{m}$ & $\sum a_{m}+b_{m}+c_{m}$ \\
\hline $\begin{array}{l}\text { SzW-sz } \\
(i=m)\end{array}$ & $a_{m}$ & $b_{m}$ & $\sum_{i=1}^{m} c_{i}$ & $\Sigma \mathrm{C}$ \\
\hline Total & $\sum_{i=1}^{m} a_{i}$ & $\sum_{i=1}^{m} b_{i}$ & $n_{i=1}$ & \\
\hline
\end{tabular}

Table 8: Calculation for inequality of aggregating indicators within BUA

\begin{tabular}{|c|c|c|}
\hline BUA mean & Inequality & Inequality $\left( \pm A_{l}\right)+\left( \pm A_{2}\right) * 100$ \\
\hline \multirow{2}{*}{$=\sum \boldsymbol{C} \div \boldsymbol{n}$} & $A_{l}=$ Maximum C-M & Inequality within BUA \\
\cline { 2 - 3 } & $A_{2}=$ Minimum $\mathrm{C}-\mathrm{M}$ & In \\
\hline
\end{tabular}

Note: $n=$ Number of sub-zones

Table 9: Computation of priority vectors on future governance of an indicator

\begin{tabular}{|l|c|c|c|c|}
\hline \multicolumn{1}{|c|}{ Five sub-zones } & $\begin{array}{c}\text { Private } \\
a_{i}\end{array}$ & $\begin{array}{c}\text { PPP } \\
b_{i}\end{array}$ & $\begin{array}{c}\text { Public } \\
c_{i}\end{array}$ & $\begin{array}{c}\text { Total of each } \\
\text { sub-region }\end{array}$ \\
\hline SzN-sz $(i=1)$ & $a_{l}$ & $b_{1}$ & $c_{l}$ & $\sum_{j=1}^{n} a_{1}$ \\
\hline SzE-sz $(i=2)$ & $a_{2}$ & $b_{2}$ & $c_{2}$ & $\sum_{j=1}^{n} b_{1}$ \\
\hline.. &.. &.. & $c_{m}$ & $\sum_{j=1}^{n} c_{1}$ \\
\hline SzW-sz $(i=m)$ & $a_{m}$ & $b_{m}$ & $\sum c_{i} / n$ & \\
\hline $\begin{array}{l}\text { Mean of each governance } \\
\text { type }\end{array}$ & $\sum a_{i} / n$ & $\sum b_{i} / n$ & $\sum$ \\
\hline
\end{tabular}

Note: $n=$ Number of sub-zones 


\section{RESULTS AND DISCUSSIONS}

Table 10, 12, and 14 present the characteristic $\left(R_{i j}\right)$, priority $\left(W_{i j}\right)$, and compounded weighting vectors (Cij) based on dwellers' preference on the three dimensions of HDI.

\subsection{DWELLERS PREFERENCES}

PRIORITIES

AND

\subsubsection{Education}

It is evident that at present (Rij) education related parameters are relatively agglomerated in Sub zone East. Distribution of this parameter is varied in nature over the other sub zones (refer Table 10). A significant extent of inequality in education also obvious as parametric range is as high as 6.00 (i.e.,
$\mathrm{SzE}-\mathrm{SzC}$ or $17.000-11.000)$. But according to dwellers' priority (Wij) education related parameters are not significantly agglomerated within any sub zone rather it is scattered in nature as it is concentrated within North Sub zone only (refer Table 11). As the parametric range is 0.161 (i.e., SzN - SzC or $0.311-0.150$ ), it seems that inequality is not very high for this indicator. This is because of dwellers' increasing awareness regarding value of education within the entire zone. From Table 10 it is also evident that parameters of education are not significantly varied in nature as the range value for $C i j$ is 0.416 (i.e., $\mathrm{SzE}-\mathrm{SzS}$ or 3.008 - 2.592). The reason is dwellers' higher preference $(\mathrm{C} i \mathrm{j})$ for good quality educational system. They are also very concerned about the total members in a family having access to the basic education based on nature/availability of educational institutions.

Table 10: Education

\begin{tabular}{|c|c|c|c|c|c|c|c|}
\hline Sub-zones & $\begin{array}{l}\text { Type of } \\
\text { vectors }\end{array}$ & $\begin{array}{l}\text { Members } \\
\text { attending } \\
\text { education }\end{array}$ & $\begin{array}{l}\text { Nature of } \\
\text { educational } \\
\text { inst. }\end{array}$ & Expenditure & Loan & Perception & Total \\
\hline \multirow{3}{*}{ SzN } & $R_{i j}$ & 2.281 & 2.730 & 3.288 & 2.456 & 2.556 & 10.581 \\
\hline & $W_{i j}$ & 0.165 & 0.165 & 0.165 & 0.311 & 0.193 & 1.000 \\
\hline & $C_{i j}$ & 0.377 & 0.451 & 0.543 & 0.764 & $\mathbf{0 . 4 9 5}$ & 2.629 \\
\hline \multirow{3}{*}{ SzE } & $R_{i j}$ & 2.200 & 3.500 & 3.750 & 3.050 & 2.500 & 17.000 \\
\hline & $W_{i j}$ & 0.221 & 0.205 & 0.214 & 0.186 & 0.174 & 1.000 \\
\hline & $C_{i j}$ & 0.486 & 0.718 & 0.801 & 0.566 & 0.436 & 3.008 \\
\hline \multirow{3}{*}{$\mathrm{SzC}$} & $R_{i j}$ & 2.333 & 2.833 & 3.308 & 2.467 & 2.658 & 11.000 \\
\hline & $W_{i j}$ & 0.239 & 0.202 & 0.230 & 0.188 & 0.150 & 1.000 \\
\hline & $C_{i j}$ & 0.485 & 0.470 & 0.675 & 0.662 & 0.409 & 2.701 \\
\hline \multirow{3}{*}{$\mathrm{SzS}$} & $R_{i j}$ & 2.714 & 2.893 & 3.036 & 2.321 & 1.929 & 12.893 \\
\hline & $W_{i j}$ & 0.208 & 0.166 & 0.204 & 0.268 & 0.154 & 1.000 \\
\hline & $C_{i j}$ & 0.599 & 0.598 & 0.594 & 0.437 & 0.364 & 2.592 \\
\hline \multirow{3}{*}{ SzW } & $R_{i j}$ & 2.588 & 2.912 & 3.015 & 2.426 & 2.309 & 13.250 \\
\hline & $W_{i j}$ & 0.221 & 0.207 & 0.196 & 0.188 & 0.189 & 1.000 \\
\hline & $C_{i j}$ & 0.619 & 0.587 & 0.692 & 0.456 & 0.347 & 2.701 \\
\hline \multicolumn{2}{|l|}{ Mean of $W_{i j}$} & 0.211 & 0.189 & 0.202 & 0.228 & 0.172 & 1.000 \\
\hline \multicolumn{7}{|l|}{ Total of $C_{i j}$} & 13.631 \\
\hline \multicolumn{7}{|c|}{ Mean of $\mathrm{C}_{\mathrm{ij}}$ (Overall BUA) } & 2.726 \\
\hline
\end{tabular}

Source: The data were collected through a questionnaire survey

Table 11: Summary table of education

\begin{tabular}{|l|c|c|c|c|c|c|c|}
\hline \multicolumn{1}{|c|}{$\begin{array}{c}\text { Type of } \\
\text { vectors }\end{array}$} & Sub-zones & $\begin{array}{c}\text { Members } \\
\text { attending } \\
\text { education }\end{array}$ & $\begin{array}{c}\text { Nature of } \\
\text { educational } \\
\text { inst. }\end{array}$ & Expenditure & Loan & Perception & Total \\
\hline$R_{i j}$ & SzE & 2.200 & 3.500 & 3.750 & 3.050 & 2.500 & 17.000 \\
\hline$W_{i j}$ & SzN & 0.165 & 0.165 & 0.165 & 0.311 & 0.193 & 1.000 \\
\hline$C_{i j}$ & \multicolumn{7}{|c|}{ Parameters are not significantly varied in nature } \\
\hline
\end{tabular}

Source: The data were collected through a questionnaire survey 


\subsubsection{Economy}

Here dwellers' present situation is attempted to characterize through Characteristic vector (Rij). Based on dwellers' responses regarding economy, it is observed that present (Rij) economic parameters are mostly agglomerated within the subzone of west (Table 12). The range of this particular indicator is comparatively not significant as it is 1.029 of the total responses ( $\mathrm{SzW}-\mathrm{SzE}$ or $12.779-11.750$ ). Hence extent of inequality is not much for this indicator and except $\mathrm{SzW}$, all the subzones have similar pattern of distribution of the parameters. It is explicit from the present scenario that dwellers are searching for more career options than previous to maintain expense of daily life and to improve standard of living. Again according to dwellers' priorities $\left(W_{i j}\right)$ all the parameters related to economy are not significantly agglomerated within any of the sub zone. Here distribution of this parameter is scattered in nature and it is concentrated within South sub zone. As dwellers are more aware of their current status of economy the range is $0.175(\mathrm{SzS}-\mathrm{SzW}$ or $0.277-0.102)$, it seems that inequality is not very high for this parameter (Table 12 and Table 13). From the table it is also evident that dwellers' preferences ( $\mathrm{C} i j)$ for economic parameters are relatively varied in nature as the range value is 0.671 (i.e., $\mathrm{SzW}-\mathrm{SzE}$ or 2.398 - 1.727). This is because of increasing consciousness among the dwellers for various career options. For family income and expenditure, dwellers' preference is highly prioritized.

Table 12: Economy

\begin{tabular}{|c|c|c|c|c|c|c|c|c|}
\hline Sub-zones & $\begin{array}{l}\text { Type of } \\
\text { vectors }\end{array}$ & $\begin{array}{l}\text { Earning } \\
\text { member }\end{array}$ & $\begin{array}{l}\text { Nature of } \\
\text { employment }\end{array}$ & $\begin{array}{c}\text { Family } \\
\text { expenditure }\end{array}$ & $\begin{array}{l}\text { Family } \\
\text { income }\end{array}$ & $\begin{array}{c}\text { Savings and } \\
\text { investment }\end{array}$ & Perception & Total \\
\hline \multirow{3}{*}{$\mathrm{SzN}$} & $R_{i j}$ & 2.081 & 2.100 & 1.938 & 1.813 & 2.125 & 2.188 & 12.244 \\
\hline & $W_{i j}$ & 0.165 & 0.132 & 0.165 & 0.165 & 0.206 & 0.165 & 1.000 \\
\hline & $C_{i j}$ & 0.344 & 0.278 & 0.320 & 0.300 & 0.438 & 0.362 & 2.042 \\
\hline \multirow{3}{*}{ SzE } & $R_{i j}$ & 2.000 & 1.750 & 1.875 & 1.175 & 1.550 & 1.670 & 11.750 \\
\hline & $W_{i j}$ & 0.262 & 0.198 & 0.170 & 0.135 & 0.113 & 0.122 & 1.000 \\
\hline & $C_{i j}$ & 0.523 & 0.347 & 0.319 & 0.159 & 0.175 & 0.203 & 1.727 \\
\hline \multirow{3}{*}{$\mathrm{SzC}$} & $R_{i j}$ & 2.033 & 2.050 & 1.942 & 1.983 & 2.025 & 2.067 & 12.100 \\
\hline & $W_{i j}$ & 0.201 & 0.191 & 0.202 & 0.137 & 0.137 & 0.131 & 1.000 \\
\hline & $C_{i j}$ & 0.409 & 0.393 & 0.393 & 0.271 & 0.278 & 0.271 & 2.014 \\
\hline \multirow{3}{*}{$\mathrm{SzS}$} & $R_{i j}$ & 2.143 & 2.286 & 1.964 & 2.071 & 1.071 & 2.357 & 11.893 \\
\hline & $W_{i j}$ & 0.277 & 0.211 & 0.176 & 0.110 & 0.091 & 0.135 & 1.000 \\
\hline & $C_{i j}$ & 0.594 & 0.482 & 0.345 & 0.228 & 0.097 & 0.319 & 2.066 \\
\hline \multirow{3}{*}{ SzW } & $R_{i j}$ & 2.559 & 2.347 & 2.309 & 2.340 & 2.318 & 2.362 & 12.779 \\
\hline & $W_{i j}$ & 0.276 & 0.189 & 0.150 & 0.117 & 0.102 & 0.166 & 1.000 \\
\hline & $C_{i j}$ & 0.705 & 0.444 & 0.346 & 0.274 & 0.238 & 0.392 & 2.398 \\
\hline \multicolumn{2}{|c|}{ Mean of $W_{i j}$} & 0.236 & 0.184 & 0.173 & 0.133 & 0.130 & 0.144 & 1.000 \\
\hline \multicolumn{8}{|c|}{ Total of $C_{i j}$} & 10.247 \\
\hline \multicolumn{8}{|c|}{ Mean of $\mathrm{C}_{\mathrm{ij}}$ (Overall BUA) } & 2.049 \\
\hline
\end{tabular}

Source: The data were collected through a questionnaire survey

Table 13: Summary table of economy

\begin{tabular}{|l|c|c|c|c|c|c|c|c|}
\hline \multicolumn{1}{|c|}{$\begin{array}{c}\text { Type of } \\
\text { vectors }\end{array}$} & $\begin{array}{c}\text { Sub- } \\
\text { zones }\end{array}$ & $\begin{array}{c}\text { Earning } \\
\text { member }\end{array}$ & $\begin{array}{c}\text { Nature of } \\
\text { employment }\end{array}$ & $\begin{array}{c}\text { Family } \\
\text { xpenditure }\end{array}$ & $\begin{array}{c}\text { Family } \\
\text { income }\end{array}$ & $\begin{array}{c}\text { Savings and } \\
\text { investment }\end{array}$ & Perception & Total \\
\hline$R_{i j}$ & SzW & 2.559 & 2.347 & 2.309 & 2.340 & 2.318 & 2.362 & 12.779 \\
\hline$W_{i j}$ & \multicolumn{8}{|c|}{ No significant agglomeration rather parameters are scattered in nature } \\
\hline$C_{i j}$ & \multicolumn{8}{|c|}{ Parameters are relatively varied in nature } \\
\hline
\end{tabular}

Source: The data were collected through a questionnaire survey 


\subsubsection{Health}

Based on assessing present $\left(R_{i j}\right)$ status of health all the parameters are highly agglomerated in Sub zone South. As the range is as high as $7.407(\mathrm{SzN}-\mathrm{SzS}$ or $11.200-18.607$ ) it seems that inequality is also very high for this parameter (Table 14) and spatial distribution of the same is significantly varied in nature. For this reason dwellers of the entire zone have expressed their aspirations for a better health care system. On the contrary, dwellers priority $\left(W_{i j}\right)$ related to health parameter are also not significantly agglomerated within any sub zone except some amount of concentration is observed within North sub zone. Here distribution of this parameter is scattered in nature. This implies the increasing demand for efficient health care in sub-zones. It is observed from Table 14 and Table 15 that dwellers' preference $(\mathrm{C} i j)$ for parameters of health are highly varied in nature as the range value is 1.538 (i.e., $\mathrm{SzS}$ - SzN or $3.772-2.234)$. This is due to the awareness for urban health and hygiene among dwellers of the entire zone which indicates high inequality in the field of health.

Table 14: Health

\begin{tabular}{|c|c|c|c|c|c|c|c|}
\hline Sub-regions & $\begin{array}{l}\text { Types of } \\
\text { vectors }\end{array}$ & $\begin{array}{l}\text { Members } \\
\text { availing } \\
\text { medical } \\
\text { services }\end{array}$ & $\begin{array}{c}\text { Nature of } \\
\text { medical } \\
\text { institutions }\end{array}$ & Expenditure & Insurance & Perception & Total \\
\hline \multirow{3}{*}{$\mathrm{SzN}$} & $R_{i j}$ & 2.063 & 2.375 & 2.331 & 2.419 & 2.013 & 11.200 \\
\hline & $W_{i j}$ & 0.149 & 0.149 & 0.254 & 0.194 & 0.254 & 1.000 \\
\hline & $C_{i j}$ & 0.307 & 0.354 & 0.592 & 0.470 & 0.511 & 2.234 \\
\hline \multirow{3}{*}{ SzE } & $R_{i j}$ & 2.750 & 2.975 & 3.225 & 2.800 & 2.825 & 14.575 \\
\hline & $W_{i j}$ & 0.331 & 0.205 & 0.180 & 0.166 & 0.118 & 1.000 \\
\hline & $C_{i j}$ & 0.910 & 0.611 & 0.579 & 0.465 & 0.334 & 2.899 \\
\hline \multirow{3}{*}{$\mathrm{SzC}$} & $R_{i j}$ & 3.033 & 2.792 & 2.950 & 2.842 & 2.900 & 14.517 \\
\hline & $W_{i j}$ & 0.311 & 0.185 & 0.157 & 0.159 & 0.188 & 1.000 \\
\hline & $C_{i j}$ & 0.668 & 0.465 & 0.629 & 0.776 & 0.367 & 2.906 \\
\hline \multirow{3}{*}{$\mathrm{SzS}$} & $R_{i j}$ & 3.929 & 4.214 & 3.679 & 3.464 & 3.321 & 18.607 \\
\hline & $W_{i j}$ & 0.220 & 0.167 & 0.213 & 0.273 & 0.127 & 1.000 \\
\hline & $C_{i j}$ & 1.160 & 0.872 & 0.628 & 0.623 & 0.489 & 3.772 \\
\hline \multirow{3}{*}{ SzW } & $R_{i j}$ & 2.853 & 2.765 & 3.029 & 1.721 & 1.897 & 12.265 \\
\hline & $W_{i j}$ & 0.295 & 0.207 & 0.171 & 0.180 & 0.147 & 1.000 \\
\hline & $C_{i j}$ & 0.888 & 0.510 & 0.476 & 0.273 & 0.357 & 2.504 \\
\hline \multicolumn{2}{|c|}{ Mean of $W_{i j}$} & 0.261 & 0.182 & 0.195 & 0.194 & 0.167 & 1.000 \\
\hline \multicolumn{7}{|l|}{ Total $C_{i j}$} & 14.315 \\
\hline \multicolumn{7}{|c|}{ Mean of $\mathrm{C}_{\mathrm{ij}}$ (Overall BUA) } & 2.863 \\
\hline
\end{tabular}

Source: The data were collected through a questionnaire survey

Table 15: Summary table of health

\begin{tabular}{|c|c|c|c|c|c|c|c|}
\hline $\begin{array}{l}\text { Type of } \\
\text { vectors }\end{array}$ & Sub-zones & $\begin{array}{l}\text { Members } \\
\text { availing } \\
\text { medical } \\
\text { services }\end{array}$ & $\begin{array}{c}\text { Nature of } \\
\text { medical } \\
\text { institutions }\end{array}$ & Expenditure & Insurance & Perception & Total \\
\hline$R_{i j}$ & $\mathrm{SzS}$ & 3.929 & 4.214 & 3.679 & 3.464 & 3.321 & 18.607 \\
\hline$W_{i j}$ & \multicolumn{7}{|c|}{ No significant agglomeration rather parameters are scattered in nature } \\
\hline \multirow{2}{*}{$C_{i j}$} & $\mathrm{SzC}$ & 0.668 & 0.465 & 0.629 & 0.776 & 0.367 & 2.906 \\
\hline & \multicolumn{7}{|c|}{ Parameters are highly varied in nature } \\
\hline
\end{tabular}

Source: The data were collected through a questionnaire survey 


\subsection{EXTENT OF INEQUALITY}

It is evident from Table 16 that extent of inequality of education in terms of dwellers' $C_{i j}$ within BUA is only $15 \%$ of BUA's mean value. Hence, the value of educational inequality is not significant. The excess indicates that spatial characteristics of dwellers' preferences are less varied and less 'agglomerated' in nature. It is also evident that dwellers of SzE have highly preferred educational parameters, which is a maxima of BUA's mean. The sub-region is evolving as a new node of growth. On the contrary, dwellers of $\mathrm{SzS}$ have already availed advanced types of educational facilities, they are subsequently less responsive to education, which is a minima of BUA's mean.

It is evident from Table 16 that extent of inequality of economic indicator within BUA is above $30 \%$ of BUA's mean value. It portrays a moderate level of economic inequality. The excess indicates that spatial characteristics of dwellers' preferences are moderately varied in nature. It is also evident that due to high cost of living in $\mathrm{SzW}$ dwellers are more concerned about their economic status and for that reason, have highly preferred economic parameters and this is a maxima of BUA's mean. Whereas dwellers of SzE are less responsive to economy, which is a minima of BUA's mean.
Extent of inequality of health in terms of dwellers $C_{i j}$ within BUA is above $50 \%$ of BUAs mean. This indicates a high level of health inequality. This indicates that spatial characteristics of dwellers' preferences for health related parameters are significantly varied and 'agglomerated' in nature. It can be inferred that dwellers of $\mathrm{SzS}$ are more concerned about their state of health care and have thus laid a high preference on health related parameters, which is a maxima of BUA's mean. Whereas, preferences of dwellers of $\mathrm{SzW}$ are relatively less for the same indicator, which is a minima of BUA's mean.

\subsubsection{Aggregate HDI: Computation of Composite Weighting Vectors}

It is explicit from Table 17 that based on the three dimensions of HDI in aggregate $(C)$ that out of the five sub-zones, four are below the BUA's average. Among them, $\mathrm{SzN}$ is the lowest with 6.905 , as dwellers preference for $C$ is the least. On the contrary, as dwellers of $\mathrm{SzS}$ responded highly (8.430 parts of 38.193) and it is well above BUA average. It implies the existence of socio-economic inequality is less within the entire zone. On the whole, it is interesting to observe from Table 18 that extent of inequality in terms of all three indicators is just $20 \%$ of BUA's mean, which is lower than all the three values computed as per individual indicators, as shown in Table 18. Hence within BUA extent of inequality is low in general.

Table 16: Inequality of indicators

\begin{tabular}{|c|c|c|c|c|c|}
\hline Indicators & $\begin{array}{l}\text { BUA } \\
\text { mean }\end{array}$ & \multicolumn{2}{|c|}{ Range } & Inequality & $\begin{array}{c}\text { Inequality } \\
\left(\mathrm{b}_{1} \pm \mathrm{a}_{1}\right)+\left(\mathrm{b}_{1} \pm \mathrm{a}_{2}\right)\end{array}$ \\
\hline \multirow{2}{*}{ Education } & \multirow{2}{*}{$\begin{array}{c}2.726 \\
\left(\mathrm{~b}_{1}\right)\end{array}$} & Maximum $(\mathrm{SzW})$ & $3.008\left(\mathrm{a}_{1}\right)$ & $0.307\left(\mathrm{~b}_{1} \pm \mathrm{a}_{1}\right)$ & \multirow{2}{*}{$0.416[=15.26]$} \\
\hline & & Minimum (SzE) & $2.592\left(\mathrm{a}_{2}\right)$ & $0.109\left(b_{1} \pm a_{2}\right)$ & \\
\hline \multirow{2}{*}{ Economy } & \multirow{2}{*}{$\begin{array}{c}2.049 \\
\left(b_{1}\right)\end{array}$} & Maximum (SzE) & $2.398\left(\mathrm{a}_{1}\right)$ & $0.349\left(\mathrm{~b}_{1} \pm \mathrm{a}_{1}\right)$ & \multirow{2}{*}{$0.672[=32.78]$} \\
\hline & & Minimum (SzS) & $1.727\left(\mathrm{a}_{2}\right)$ & $0.323\left(b_{1} \pm a_{2}\right)$ & \\
\hline \multirow{2}{*}{ Health } & \multirow{2}{*}{$\begin{array}{c}2.863 \\
\left(\mathrm{~b}_{1}\right)\end{array}$} & Maximum (SzS) & $3.772\left(\mathrm{a}_{1}\right)$ & $0.909\left(b_{1} \pm a_{1}\right)$ & \multirow{2}{*}{$1.538[=53.73]$} \\
\hline & & Minimum (SzW) & $2.504\left(\mathrm{a}_{2}\right)$ & $0.629\left(b_{1} \pm a_{2}\right)$ & \\
\hline
\end{tabular}

Table 17: $C$ aggregating three dimensions of HDI

\begin{tabular}{|l|c|c|c|c|}
\hline \multicolumn{1}{|c|}{ Sub-regions } & $\begin{array}{c}\text { Total weighting of } \\
\text { education }\end{array}$ & $\begin{array}{c}\text { Total weighting of } \\
\text { economy }\end{array}$ & $\begin{array}{c}\text { Total weighting of } \\
\text { health }\end{array}$ & Composite weighting \\
\hline SzN & 2.042 & 2.629 & 2.234 & $\mathbf{6 . 9 0 5}$ \\
\hline SzE & 1.727 & $\mathbf{3 . 0 0 8}$ & 2.899 & 7.633 \\
\hline SzC & 2.014 & 2.701 & 2.906 & 7.621 \\
\hline SzS & 2.066 & 2.592 & $\mathbf{3 . 7 7 2}$ & $\mathbf{8 . 4 3 0}$ \\
\hline SzW & $\mathbf{2 . 3 9 8}$ & 2.701 & 2.504 & 7.603 \\
\hline Total & 10.247 & 13.631 & 14.315 & 38.193 \\
\hline & & & BUA mean & 7.639 \\
\hline
\end{tabular}

Source: The data were collected through a questionnaire survey 
Table 18: Assessment of inequality variation based on $C$ : Overall HDI indicators

\begin{tabular}{|c|c|c|c|c|}
\hline \multirow{2}{*}{$\begin{array}{c}\text { BUA mean } \\
{[38.193 / 5)}\end{array}$} & \multicolumn{2}{|c|}{ Range } & Inequality & $\begin{array}{c}\text { Inequality variation } \\
\left(\mathrm{b}_{1} \pm \mathrm{a}_{1}\right)+\left(\mathrm{b}_{1} \pm \mathrm{a}_{2}\right) \\
{[\text { mean \%] }}\end{array}$ \\
\hline \multirow{2}{*}{$7.639\left(\mathrm{~b}_{1}\right)$} & Maximum $(\mathrm{SzS})$ & $8.430\left(\mathrm{a}_{1}\right)$ & $0.791\left(\mathrm{~b} 1 \pm \mathrm{a}_{1}\right)$ & \multirow{2}{*}{$1.525[=19.96]$} \\
\cline { 2 - 4 } & Minimum $(\mathrm{SzN})$ & $6.905\left(\mathrm{a}_{2}\right)$ & $0.734\left(\mathrm{~b} 1 \pm \mathrm{a}_{2}\right)$ & \\
\hline
\end{tabular}

Source: The data were collected through a questionnaire survey

Table 19: Aggregate global priority vectors of future governance

\begin{tabular}{|c|l|c|c|c|c|}
\hline Sub-regions & Indicators & Private & PPP & Public & Total \\
\hline \multirow{4}{*}{ SzN - Mean } & Education & 0.295 & 0.288 & 0.417 & 1.00 \\
\cline { 2 - 6 } & Economy & 0.333 & 0.300 & 0.167 & 1.00 \\
\cline { 2 - 6 } & Health & 0.320 & 0.224 & 0.256 & 1.00 \\
\hline \multirow{5}{*}{ SzE - Mean } & Education & 0.319 & 0.356 & 0.325 & 1.00 \\
\cline { 2 - 6 } & Economy & 0.316 & 0.344 & 0.341 & 1.00 \\
\cline { 2 - 6 } & Health & 0.357 & 0.374 & 0.269 & 1.00 \\
\hline \multirow{3}{*}{ SzC - Mean } & Education & 0.331 & 0.350 & 0.319 & 1.00 \\
\cline { 2 - 6 } & Economy & 0.344 & 0.386 & 0.269 & 1.00 \\
\cline { 2 - 6 } & Health & 0.401 & 0.298 & 0.301 & 1.00 \\
\hline \multirow{3}{*}{ SzW - Mean } & Education & 0.345 & 0.337 & 0.319 & 1.00 \\
\cline { 2 - 6 } & Economy & 0.343 & 0.404 & 0.253 & 1.00 \\
\cline { 2 - 6 } & Health & 0.395 & 0.300 & 0.304 & 1.00 \\
\cline { 2 - 6 } & Education & 0.367 & 0.319 & 0.313 & 1.00 \\
\cline { 2 - 6 } & Economy & 0.316 & 0.379 & 0.305 & 1.00 \\
\hline \multirow{3}{*}{ Mean } & Health & 0.318 & 0.381 & 0.301 & 1.00 \\
\cline { 2 - 6 } & Education & 0.331 & 0.330 & 0.339 & 1.00 \\
\cline { 2 - 6 } & Economy & $\mathbf{0 . 3 3 0}$ & $\mathbf{0 . 3 6 3}$ & $\mathbf{0 . 2 6 7}$ & 1.00 \\
\hline & Health & $\mathbf{0 . 3 5 8}$ & $\mathbf{0 . 3 1 5}$ & $\mathbf{0 . 2 8 6}$ & 1.00 \\
\hline
\end{tabular}

Source: The data were collected through a questionnaire survey

\subsection{ASSESSMENT BASED ON DWELLERS' STATED PRIORITY AND PREFERENCE FOR FUTURE URBAN GOVERNANCE}

In this section, assessment on weightings of future options of governance has been presented. Table 19 has furnished the stated preferences of nature of governance with respect to the three dimensions of HDI. Within all sub zones, dwellers' preferences are varied from ppp to private type governance for the educational indicator. A moderately high range of preference is reflected for private governance as future option. The preference is mainly agglomerated within the sub zones of $\mathrm{SzC}, \mathrm{SzS}$, and $\mathrm{SzW}$. Future preference of public governance for education is less preferred by the dwellers across all sub zones, except SzN. This is homogeneously distributed over all the sub zones. Table 19 also shows that dwellers from all sub zones, except SzN, have highlighted preference for $p p p$ as future governance in economy and agglomerated over the sub zones. Dwellers' least preference has been observed for the public governance and it is spatially varied in nature. Preferences for private governance are homogeneously distributed over five sub-zones. It is evident from the table that dwellers from $\mathrm{SzN}, \mathrm{SzC}$, and $\mathrm{SzS}$ have highlighted preferences for private governance in health as a future option and these are said to be agglomerated within these sub zones. This preference also said to be scattered within $\mathrm{SzE}$ and $\mathrm{SzW}$ and these are closely ranged. Public sector is least preferred by dwellers in all the sub zones as desired governance of health and it is homogeneously distributed over the space.

\section{CONCLUSIONS}

On the whole, results and interpretations of analyses of local data imply that agglomerative nature of socio-economic inequality regarding composite set of HDI indicators is comparatively less for educational indicators. Agglomerative nature of socio-economic inequality is relatively higher for health indicators followed by economic indicators across spatial configuration of BUA. It is evident that dwellers from the entire area are 
availing relatively better quality of educational infrastructure, still they are more aware and willing to pay for the best quality education, which is modern and having state-of-the-art facilities. For this reason, as a future strategy, dwellers' confirm their preference for public type governance in augmenting the strengths and opportunities in education system. As dwellers are enjoying a relatively higher access to career planning opportunities, they have given high preference for maximum number of earning members in their families to sustain the high urban expenditure pattern. Dwellers in general have preferred public governance for augmenting prospects of job sectors and investment sectors in boosting economic system of BUA. There is a strategic demand to develop proper health care system for the entire BUA, which can be ideally met by $p p p$ type governance. Dwellers from all sub-regions have preferred for $p p p$ type government. To fill up the deficiency in health sector in terms of number of health institutions and auxiliary health care services, proper strategies on social health awareness, can be governed by $p p p$ type governance.

The paper recommends further investigations of normative aspects of socio-economic development characterized by gender, ethnicity, race, and culture (Panda \& Agarwal, 2005). Future researches may be carried out by collating areas like socio-economic and environmental vulnerability and resilience in the context of inequality within an urban agglomeration. Finally, a comparative standpoint of multiple inequality assessments governed by different aspects of quality of life and covering a range of urban agglomeration situation may be conducted to arrive at a holistic research platform.

In conclusion, selection of parameters and assessing them to measure socio-economic inequality within an urban agglomeration is always a challenging work. This paper has tried to select best possible parameters at present time keeping their aspirations in mind. Here the results and interpretations, and overall findings on preferences as drawn from the analyses of local data have established the significance of application of HDI based indicators. The present study also established the methodology to measure socio-economic inequality within an urban agglomeration and how to combat that from dwellers' perspective.

\section{REFERENCES}

Aluwahlia, I. J. (2010). We should aspire and work for prosperity. Business and Economy, 4, 2 April - 15 April, pp. 58-59.
Anderson, W. P., Kanaroglou, P. S. \& Miller, E. J. (1996). Urban form, energy and environment: A review of issues, evidence and policy. Urban Studies, 33(1), pp. 735 .

Atkinson, A. B. (1992). The urban bioregion as 'sustainable development' paradigm. Third World Planning Review, 14(4), pp. 327354.

Bartsch, B. (2011). Building a better quality of life, picture of the future: Asian green city index. Siemens, pp. 24-26.

Bhaumik, S. K., \& Chakrabarty, M. (2006). Earnings inequality in India: Has the rise of caste and religion based politics in India had an impact? William Davidson Institute Working Papers Series 819, William Davidson Institute at the University of Michigan.

Birdsall, N., Lustig, N., \& Mcleod, D. (2011). Declining inequality in Latin America: Some economics, some politics. Working Paper 251, Washington DC.

Burgess, R., \& Jenks, M. (2000). Compact cities: Sustainable urban forms for developing countries. London: Spon Press.

Cladera, J. R., Marmolejo, Duarte C. R. M., \& Moix M. (2009). Urban structure and polycentrism: Towards a redifinition of the sub-centre concept. Urban Studies, 46(13), pp. 2841-2868.

Charlesworth, J., \& Cochrane, A. (1994). Tales of the suburbs: The local politics of growth in the South East of England. Urban Studies, 31, pp. 1723-1738.

Desai, M., Rachet, B., Coleman, M. P., \& McKee, M. (2010). Two countries divided by a common language: Health systems in the UK and USA. Journal of the Royal Society of Medicine, 103(7), pp. 283-287.

Dick, H. W., \& Rimmer, P. (1998). Beyond the third world city: The new urban geography of South-East Asia. Urban Studies, 35, pp. 2303-2322.

Directorate of Census Operations of Karnataka, [online], [Accessed on: $18^{\text {th }}$ January, 2013], Available from: http://censuskarnataka.gov.in/.

Feenstra, R. C. \& Hanson, G. H. (1996). Globalization, outsourcing, and wage inequality. American Economic Review, American Economic Association, 86(2), pp. 240-245. Retrieved from, http://www.pkarchive.org/economy/CNB CWSJReport072405.html

Gallardo, G. (2009). The human development index as an effort to measure well-being in Hondurus. The Third OECD World Forum on 'Statistics, Knowledge, and policy', Charting Progress, Building 
Visions, Improving Life, Busan, Korea, 27-3- October, 2009.

Human Development Reports. (1990). [online] Retrieved from, June 28, 2011 from, http://hdr.undp.org/en/reports/global/hdr1 990/

Human Development Reports. (2013). [online] Retrieved from, March 29, 2014 from, http://hdr.undp.org/en/statistics/ihdi/

Kanbur, R., Venables, A. J., \& Wan, G. (2006). Spatial disparities in human development: An overview of the Asian evidence, spatial disparities in human development: Perspectives from Asia. Tokyo: United Nations University Press.

Ke, S., Song, Y., \& He, M. (2009). Determinants of urban spatial scale: Chinese cities in transition, Urban Studies, 13, pp. 27952813.

Kim, S. (2008). Spatial inequality and economic development: Theories, facts, and policies. Commission on Growth and Development. Working Paper No. 16. Washington D.C: World Bank

Kundu, A. (1992). Urban development and urban research in India. New Delhi: Khama Publications.

Panda, P., \& Agarwal, B. (2005). Marital violence, human development and women's property status in India. World Development, 3(5), pp. 823-850.

Phelps, N.A. (2004). Clusters, dispersion and the spaces in between: For an economic geography of the banal. Urban Studies, 41, pp. 971-989.

Pinelopi, K. G., \& Pavcnik, N. (2007). Distributional effects of globalization in developing countries. Journal of Economic Literature, 45(1), pp. 39-82.

Planning Commission Government of India. (2002). [online] Retrieved September 22, 2011,

from, http://planningcommission.nic.in/reports/ genrep/pl_vsn2020.pdf

Saaty, T. L., \& Kearns, K. P. (1985). Analytic planning: The organization of systems. New York: Pergamon Press.

Schretzenmayr, M. K., Ritterhoff, F., \& Siebel, W. (2009). In quest of the good urban life: Socio-spatial dynamics and residential building stock transformation in Zurich. Urban Studies, 13, pp. $273-2747$.

Shukla, R., \& Bauer, M. (2009). Construction and validation of 'science culture index'. Results from comparative analysis of engagement, knowledge and attitudes to science: India and Europe. Working paper 100, Supported by: Royal society UK, London and Delhi

Sivaramakrishnan, K. C., Kundu, A., \& Singh, B. N. (2005). Handbook of urbanization in India. New Delhi: Oxford University Press.

Sun, C. C., Lin, G. T. R., \& Tzeng, G. H. (2009). The evaluation of cluster policy by fuzzy MCDM: Empirical evidence from Hsin Chu Science Park. Expert Systems with Applications: An International Journal Archive, 36(9), 11895-11906.

Tai-Kei, A., \& Coates, P. (2002). Citizen participation: Legitimizing performance measurement as a decision tool, Government Finance Review, 10(8).

Vanneman, R., \& Dubey, A. (2010). Horizontal and vertical inequalities in India: india human development survey. Working Paper No. 16, Supported by: NCAER and University of Maryland, Delhi and US.

Wall Street Journal Report (2005). [online] Brief review of world quality of life. Retrieved March 21, 2011, from, http://www.pkarchive.org/economy/CNB CWSJReport072405.html 